\title{
Production of compound mineral fertilizers as a method of utilization of waste products in chemical company Alwernia S.A.
}

\author{
Przemysław Malinowski ${ }^{1,2}$, Mirosław Olech ${ }^{3}$, Józef Sas ${ }^{1}$, Wiesław Wantuch ${ }^{3}$, Andrzej Biskupski ${ }^{1}$, \\ Leszek Urbańczyk ${ }^{3}$, Mieczysław Borowik ${ }^{1}$, Jerzy Kotowicz ${ }^{3}$ \\ ${ }^{1}$ Fertilizers Research Institute, al. 1000-lecia PP 13 A, 24-110 Putawy, Poland \\ ${ }^{2}$ The State School of Higher Vocational Education in Nysa, ul. Armii Krajowej 7, 48-300 Nysa, Poland, \\ e-mail: pmalinowski@pwsz.nysa.pl \\ ${ }^{3}$ Chemical Company Alwernia S.A., ul. K. Olszewskiego 25, 32-566 Alwernia, Poland
}

\begin{abstract}
The results of investigations on a possible utilization of waste products formed during the production of commercial and food inorganic salts are presented. Application of wastes in the production of compound fertilizers was suggested. The work covered a full research cycle starting from laboratory tests and ending on the production implementation. Fertilizer formulas were developed on the basis of laboratory tests. A possible production of fertilizers of suggested compositions was tested on a pilot plant scale. The compound fertilizer production with the use of waste raw materials was implemented in Chemical Company Alwernia S.A. It reduced the amount of wastes directed to industrial waste site.
\end{abstract}

Keywords: fertilizer, compound fertilizer, waste product, by-product.

\section{INTRODUCTION}

Chemical Company ALWERNIA Co.Ltd. are an important producer of commercial and food phosphoric salts, magnesium sulfate, calcium and magnesium nitrates. Various by-products in the form of the post-filtration sludge are formed during the production of the mentioned compounds. Wet process phosphoric acid, neutralized with soda, is used for the production of commercial and food phosphoric salts. Most impurities, mainly calcium and magnesium compounds, are separated then. After the neutralization stage sodium phosphate solution is concentrated and further purified. The so-called "phosphate sludge", formed as the result of neutralization and purification contains substantial amounts of phosphorus and also sodium. The production of magnesium sulfate consists in the decomposition of the dead-burnt magnesite with sulfuric acid. After the reaction magnesium sulfate solution is separated from the solid phase in a filter press. The separated precipitate, the so-called "magnesium slurry", contains calcium, magnesium and sulfur. Two other byproducts formed during the production of calcium and magnesium nitrates contain also nitrogen, beside calcium and magnesium. The products are formed, just like in the case of the magnesium slurry, in the filtration stage of calcium and magnesium nitrates solutions which were formed in the reaction of nitric acid with hydrated lime or dead-burnt magnesite. So far the by-products were not utilized in any way but stored on the industrial waste site. All of the mentioned by-products contain nutrients indispensable for proper plant development so they can be used for fertilizer production. Such solution is also beneficial for the environment because it reduces mining of raw materials and the amount of waste product directed to the waste site. The economical profits are also very important because fertilizer production costs and waste storage costs are reduced.

If the post-filtration sludge is to be used in fertilizer production it must be dissolved with an acid. We assume that the spent acid formed as a by-product in the production of glycerol trinitrate and isooctyl nitrate will be used for that purpose. Previous studies indicate that the acid can be used for the production of compound fertilizers on the phosphate rock basis ${ }^{1}$.

\section{EXPERIMENTAL}

Pilot plant tests of fertilizer production process were carried out in INS granulation plant of compound fertilizers ${ }^{2}$. Raw materials in a pulp form were fed to the paddle granulator with a peristaltic pump. The recycled material and loose raw materials were also fed to the granulator. Final rolling of the granular product took place on a granulation pan and then the product was directed to a dryer. The dried product was sieved to get the right particle size. The undersize and oversize product and part of the right fraction were recycled. The amount of the recycled material directed to the granulator was adjusted with a screw feeder (the excess amount was withdrawn from the system to a buffer tank and introduced to the system when necessary). After each granulation test the whole product was withdrawn from the system and divided into fractions. The fraction of the right particle size and the selected samples of the half-finished products were analysed and their functional properties (chemical analysis, particle size, mechanical strength, hygroscopicity and susceptibility to caking) were determined ${ }^{3,4}$. Size Grade Number (SGN) and Uniformity Index (UI) were calculated for the fertilizers produced on a commercial scale. The coefficients are indispensable for the assessment of fertilizers in terms of their use for the preparation of fertilizer mixtures ${ }^{5}$.

Commercial and waste products were used as raw materials in the tests. The commercial products were the following: sulfuric acid $\left(94 \% \mathrm{H}_{2} \mathrm{SO}_{4}\right)$, potassium sulfate $\left(50 \% \mathrm{~K}_{2} \mathrm{O}\right)$, potassium chloride $\left(58 \% \mathrm{~K}_{2} \mathrm{O}\right)$, ammonium sulfate $(20 \% \mathrm{~N})$, granular and crystalline urea $(46 \% \mathrm{~N})$. Table 1 shows the results of the selected determinations on the applied waste raw materials.

First, the possibility of fertilizer production on the basis of magnesium slurry and urea was investigated. Urea in 
Table 1. The results of the selected determinations in waste raw materials

\begin{tabular}{|c|c|c|c|c|c|c|c|c|c|}
\hline \multirow{3}{*}{ No. } & \multirow{3}{*}{ Raw material } & \multicolumn{8}{|c|}{ Determination result, wt. $\%$} \\
\hline & & \multicolumn{3}{|c|}{ Weight loss in temperature, ${ }^{\circ} \mathrm{C}$} & \multirow{2}{*}{$\mathrm{N}$} & \multirow{2}{*}{$\mathrm{P}_{5} \mathrm{O}_{5}$} & \multirow{2}{*}{$\mathrm{CaO}$} & \multirow{2}{*}{$\mathrm{MgO}$} & \multirow{2}{*}{$\mathrm{SO}_{3}$} \\
\hline & & 105 & 400 & 1000 & & & & & \\
\hline 1 & Magnesium slurry & 35.78 & 43.26 & 55.37 & - & - & 4.27 & 19.26 & 13.58 \\
\hline 2 & Phosphate sludge & 51.53 & 58.31 & 58.45 & - & 22.24 & - & - & - \\
\hline 3 & $\begin{array}{l}\text { By-product from calcium nitrate } \\
\text { production }\end{array}$ & 38.34 & 42.14 & - & 4.26 & - & 19.39 & - & - \\
\hline 4 & $\begin{array}{l}\text { By-product from magnesium nitrate } \\
\text { production }\end{array}$ & 28.36 & - & - & 3.24 & - & 1.86 & 23.46 & - \\
\hline 5 & Spent acid & - & - & - & 1.81 & - & - & - & 53.85 \\
\hline
\end{tabular}

Table 2. The raw materials used in individual plant scale tests

\begin{tabular}{|c|c|c|c|c|c|c|c|c|c|c|c|}
\hline \multirow[b]{2}{*}{ 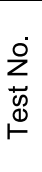 } & \multirow[b]{2}{*}{ Fertilizer formula } & \multicolumn{10}{|c|}{ Raw material $^{*}$} \\
\hline & & $r$ & N & $m$ & $\nabla$ & $\omega$ & $\begin{array}{l}\text { O্ }^{+} \\
\text {I }\end{array}$ & $\begin{array}{l}\text { O઼ } \\
\text { ઼ָ } \\
\end{array}$ & $\bar{y}$ & 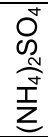 & $\begin{array}{l}\frac{N}{N} \\
\frac{1}{Z} \\
0 \\
0\end{array}$ \\
\hline 1 & $\mathrm{~N}(\mathrm{MgS})$ 12-25-8.5 & + & - & - & - & - & - & - & - & - & + \\
\hline 2 & $\mathrm{~N}(\mathrm{MgS}) 22-9-10.5$ & + & - & - & - & - & + & - & - & - & + \\
\hline 3 & PK(MgS) 15-25(5-5) & + & + & - & - & - & + & - & + & - & - \\
\hline 4 & PK(MgS) 15-25(5-5) & + & + & - & - & + & - & - & + & - & - \\
\hline 5 & NPK(MgS) 5-12-15 (5-10) & + & + & - & - & - & + & - & + & + & - \\
\hline 6 & NPK(MgS) 5-12-15 (5-10) & + & + & - & - & + & - & + & - & + & - \\
\hline 7 & NPK(MgS) 5-12-15 (5-10) & + & + & + & + & + & - & - & + & + & - \\
\hline 8 & NPK(MgS) 5-12-15 (5-10) & + & + & - & - & + & - & - & + & + & - \\
\hline 9 & NPK(MgS) 5-12-15 (5-10) & + & + & - & - & - & - & - & + & + & - \\
\hline
\end{tabular}

the ready fertilizer would be bound into an adduct form with magnesium and calcium sulfates which should provide very good physicochemical properties of the products (high mechanical strength of granules, low hygroscopicity $)^{5}$. Two process options of the production of fertilizers of the formulas: $\mathrm{N}(\mathrm{MgS})$ 12-25-8.5 and $\mathrm{N}(\mathrm{MgS})$ 22-9-10.5 were proposed. The fertilizers would be used in horticulture and for the preparation of fertilizer mixtures. In the first option, the pulp formed by mixing the urea with magnesium slurry is granulated. In the other option, there would be a decomposition stage of undissolved magnesite, contained in the waste product, with sulfuric acid then neutralization of excess acid with lime, mixing of the formed intermediate product with urea and then the granulation of the formed pulp just like in the first option.

The next investigation stage covered studies on the possibility of a simultaneous utilization of the post-filtration sludge, formed in various processes, for fertilizer production. Two fertilizer formulas, which can be obtained with the use of raw materials being studied, were suggested on the basis of laboratory tests, namely: PK(MgS) 15-25 (5-5) and NPK(MgS) 5-12-15 (5-10). Fertilizers of proposed formulas are offered by many Polish and foreign producers and they can be applied on almost all crops. The production of fertilizers of such composition consists in the granulation of the pulp prepared by the decomposition of the post-filtration sludge with sulfuric acid.

Several production tests of compound fertilizers of the proposed formulas were carried out on a pilot plant scale. Table 2 lists the raw materials used in individual tests. Tests Nos. 8 and 9 were carried out in a bit different way than the other ones. In test No.8 phosphate sludge was divided into two parts; one was fed to the system in the form of the phosphate-magnesium pulp and the other one with the stream of loose raw materials. Test No.9 was carried out without the stage of dissolution with an acid and pulp formation: raw materials were just mixed and granulated with the use of steam.

\section{DISCUSSION OF RESULTS}

The tests which were carried out gave products of a bit higher moisture content than it was planned (max. 3\%), which resulted in the reduced nutrient content and lower mechanical strength (Table 3). The situation was caused by too low dryer capacity. When the granules were properly dried their mechanical strength was substantially higher. The granules of the fertilizer produced with potassium sulfate (Test No.6) and of that prepared without the stage of acid solubilization (Test No.9) had the lowest mechanical strength. The products of the other tests had acceptable granule strength (about $30 \mathrm{~N}$ and even higher). The equivalent diameter of the most prepared granular products was about $3 \mathrm{~mm}$ which is characteristic of the INS semi-commercial plant. It was found that all types of the fertilizers produced in the tests had moderate hygroscopicity and low susceptibility to caking.

On the basis of the results of the pilot plant scale tests a process design of the compound fertilizer production with the use of by-products was developed and Chemical Company ALWERNIA S.A. decided to build a plant whose simplified flow sheet is presented in Fig.1. At present the Company produces the following fertilizers: NPK $(\mathrm{MgNaS})$ 5-9-18 (5-5-20), NPK(MgS) 3.5-8-15 (228). The offer covered also the following fertilizers: $\mathrm{PK}(\mathrm{MgNaS})$ 11-30 (6-4-10) and $\mathrm{PK}(\mathrm{MgNaS})$ 11-24 (8-4$10)$. The fertilizer production process in the plant is similar to the method applied in pilot plant tests. The ferti- 
Table 3. The properties of the products prepared in plant scale tests

\begin{tabular}{|c|c|c|c|c|c|c|c|c|c|c|c|c|}
\hline \multirow[b]{2}{*}{ 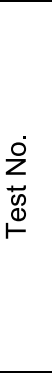 } & \multicolumn{7}{|c|}{ Content, wt.\% } & \multirow[b]{2}{*}{ 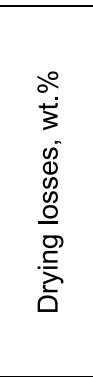 } & \multirow{2}{*}{ 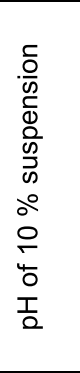 } & \multirow{2}{*}{ 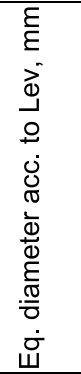 } & \multirow[b]{2}{*}{$\begin{array}{l}z \\
w \\
0 \\
\Phi \\
\Phi \\
\frac{D}{0} \\
\frac{w}{1}\end{array}$} & \multirow{2}{*}{ 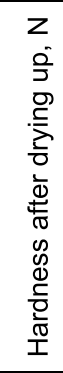 } \\
\hline & $\mathbf{z}$ & $\begin{array}{l}\overline{\widetilde{\pi}} \\
\stackrel{0}{0} \\
0 \\
0 \\
0 \\
0\end{array}$ & $\begin{array}{l}{ }^{*} \dot{D} \\
\dot{u} \\
O_{0}^{\infty} \\
0^{N}\end{array}$ & 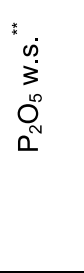 & O্ָ & $\stackrel{\circ}{\Sigma}$ & $\omega$ & & & & & \\
\hline 1 & 12.13 & - & - & - & - & 24.85 & 8.96 & 3.84 & 7.21 & 3.23 & 70.2 & - \\
\hline 2 & 21.44 & - & - & - & - & 8.16 & 9.93 & 1.78 & 6.26 & 2.39 & 42.0 & - \\
\hline 3 & - & 14.09 & 14.07 & 3.91 & 23.0 & 6.28 & 3.88 & 6.78 & 5.90 & 2.78 & 23.7 & 27.8 \\
\hline 4 & - & 9.81 & 9.53 & 4.05 & 16.16 & 4.75 & 11.41 & 8.55 & 5.60 & 3.35 & 26.0 & 33.0 \\
\hline 5 & 4.59 & 8.49 & 8.46 & 1.31 & 14.09 & 4.10 & 10.26 & 4.59 & 6.33 & 2.72 & 19.2 & 26.7 \\
\hline 6 & 3.89 & 11.68 & 11.63 & 4.12 & 13.1 & 3.30 & 10.56 & 6.98 & 5.90 & 2.90 & 13.7 & 16.5 \\
\hline 7 & 5.34 & 12.15 & 12.15 & 2.50 & 13.98 & 3.04 & 9.06 & 6.96 & 5.80 & 1.85 & 26.0 & 51.0 \\
\hline 8 & 4.69 & 9.22 & 9.17 & 3.98 & 16.69 & 2.81 & 12.10 & 10.27 & 6.2 & 3.49 & 12.0 & 38.0 \\
\hline 9 & 4.13 & 10.77 & 10.58 & 1.26 & 12.97 & 7.25 & 10.38 & 16.7 & 5.90 & 2.33 & 10.0 & 27.0 \\
\hline
\end{tabular}

"soluble in neutral ammonium citrate

"soluble in water

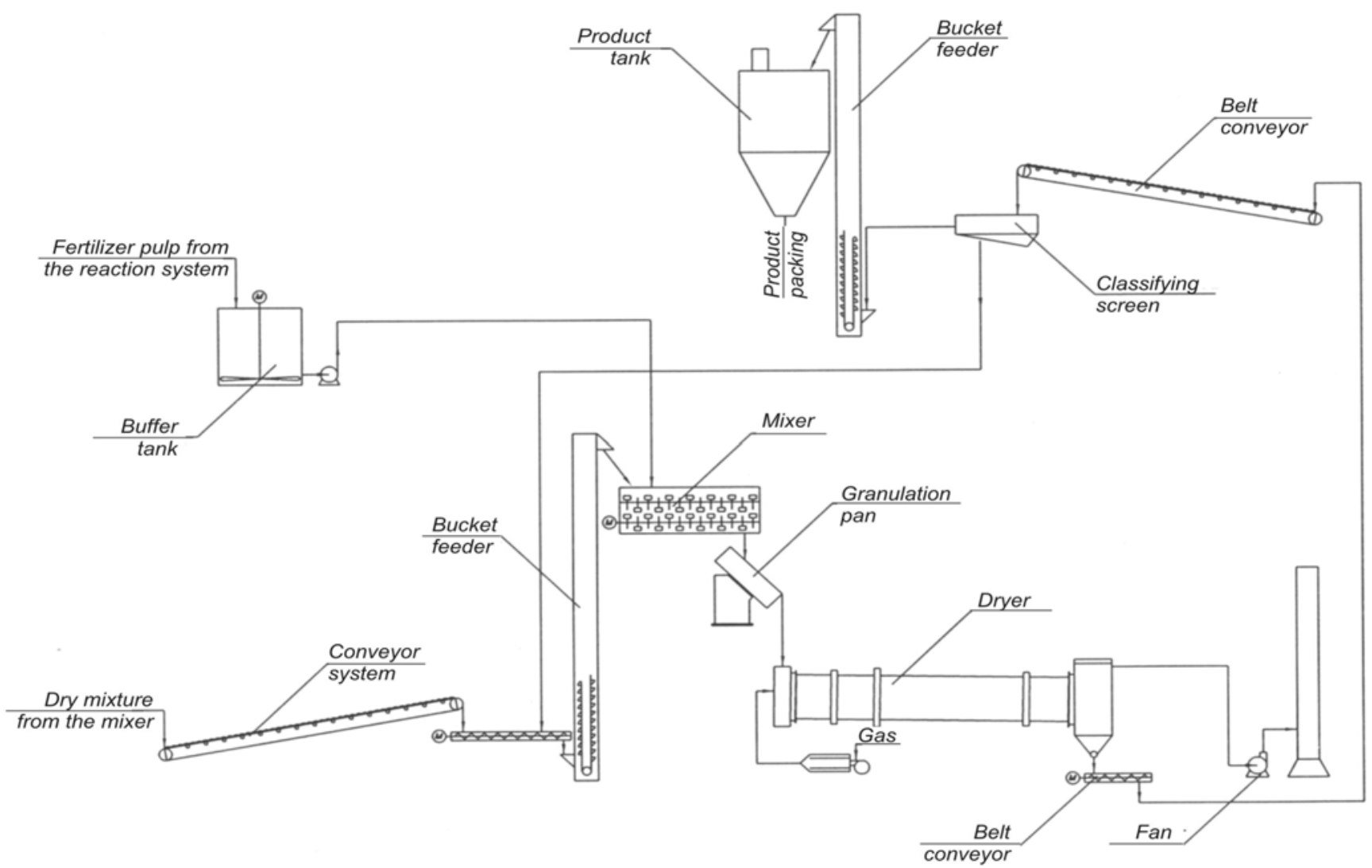

Figure 1. Simplified flow sheet of the industrial plant for production of compound fertilizers in Chemical Company ALWERNIA S.A.

lizer pulp formed by the decomposition of magnesium slurry with sulfuric acid, the mixture of loose raw materials (phosphate sludge, potassium chloride or sulfate, ammonium sulfate) and the recycled material are fed to a paddle mixer. The pulp formed by the dissolution of phosphate sludge in sulfuric acid is applied in the production of some fertilizers, then magnesium slurry - $\mathrm{Mg}$ source - is added to the prepared mixture and fertilizer production process is carried out in a production line identical with the described one. The initial granular product is directed to a granulation pan, next to a dryer and then via the conveyor system to a classifying screen. The fraction of the required size is directed to a storage bin and the undersize and ground oversize granules are directed to the paddle mixer. Table 4 presents the basic properties of the produced fertilizers. Grain size and granule mechanical strength indicate that fertilizers produced now have very similar properties to those of the multi-component fertilizers offered by other Polish and foreign producers.

\section{CONCLUSIONS}

Production of compound fertilizers on the basis of poor quality raw materials is beneficial both economically and 
Table 4. The properties of the fertilizers produced in Chemical Company ALWERNIA S.A.

\begin{tabular}{|c|l|c|c|c|c|c|}
\hline \multirow{2}{*}{ No. } & \multirow{2}{*}{ Fertilizer formula } & \multicolumn{2}{|c|}{ Factors describing grain size } & \multicolumn{2}{c|}{ Factors describing hardness } \\
\cline { 3 - 7 } & $\begin{array}{c}\text { Eq. diameter acc. } \\
\text { to Lev, } \mathrm{mm}\end{array}$ & SGN & $\begin{array}{c}\text { Granule diameter, } \\
\mathrm{mm}\end{array}$ & 3.76 & 49.1 \\
\hline 1 & $\begin{array}{l}\text { PK(MgNaS): } \\
11-30(6-4-10)\end{array}$ & 2.50 & 259.9 & 19.9 & 4.07 & 25.3 \\
\hline 2 & $\begin{array}{l}\text { PK(MgNaS): } \\
11-24(8-4-10)\end{array}$ & 1.38 & 81.1 & 55.5 & 3.97 & 38.8 \\
\hline 3 & $\begin{array}{l}\text { NPK (MgNaS) } \\
5-9-18(5-5-20)\end{array}$ & 3.19 & 356.3 & 50.2 & 3.71 & 39.9 \\
\hline 4 & $\begin{array}{l}\text { NPK (MgS) } \\
3.5-8-15(2-28)^{*}\end{array}$ & 2.28 & 259.9 & & 3 \\
\hline
\end{tabular}

"fertilizers produced at present

ecologically. During the production of commercial inorganic salts in Chemical Company ALWERNIA S.A. the by-products which are valuable from the fertilizer point of view are formed. INS in Puławy carried out tests on a laboratory and pilot plant scale to check the production possibility of compound fertilizers on the basis of the by products. The test results were successful so the process design was developed and it was decided that the compound fertilizer production plant would be built in the Company. The experience gained from the initial plant operation period led to some modifications of the produced fertilizer compositions and work is continued on the improvement of their physicochemical properties.

\section{LITERATURE CITED}

1. Biskupski, A., Malinowski, P. \& Kopeć, A., (2003). Utilization of waste acids from the nitration process for phosphorus containing fertilizers. In H. Górecki \& Z. Dobrzański (Eds.), Chemicals in sustainable agriculture, Chemistry for Agriculture, vol. 4 (pp. 65-69). Praha, Cz: Czech-Pol Trade.

2. Biskupski, A., Malinowski, P., Igras, J., Borowik, M., Podleśna, A. \& Schab, S. (2009). Nitrogen granular fertilizers - current status and perspectives of development in Poland. Przem. Chem. 12, 1337-1341. in Polish.

3. Regulation (EC) No 2003/2003 of the European Parliament and of the Council of 13 October 2003 relating to fertilizers. Official Journal of the European Union L 304/1.

4. Pawlikowski, S. \& Szymonik, S. (1959). About the methodology of determining the hygroscopicity. Przem. Chem. 8, 598-599. in Polish.

5. Lance, G. E. N. (1996). Fertilizer Blending - Theory. The International Fertilizer Society - Proceeding 387. York, UK: IFS.

6. Malinowski, P., Biskupski, A. \& Głowiński, J. (2007). Preparation methods of calcium sulphate and urea adduct. Pol. J. Chem. Tech. 9(4), 111-114. DOI: 10.2478/v10026-0070102-z. 